\title{
ENERGY CONSUMPTION OF RAIL BALTICA PROJECT: REGIONAL ASPECTS OF ENVIRONMENTAL IMPACT
}

\author{
Olga Piterina $^{1}$, Alexander Masharsky ${ }^{2}$ \\ ${ }^{I}$ The Baltic International Academy, Riga, Latvia, olga@ekoair.lv \\ ${ }^{2}$ The Baltic International Academy, Riga, Latvia,a_mash@inbox.lv
}

\begin{abstract}
Research purpose. The high-speed railway (HSR) construction project in the Baltic States is the largest joint infrastructure project since the restoration of independence of Latvia, Lithuania and Estonia. Rail Baltica (RB) is considered as the most energy-efficient project having the lowest environmental impact. However, the issue of energy consumption of the project was not sufficiently addressed either in the investment justification of the RB construction or in the relevant research works regarding the project. The aim of the current research is to determine the indicators of energy consumption and carbon dioxide $\left(\mathrm{CO}_{2}\right)$ emissions intensity of the Latvian section of $\mathrm{RB}$, since they are the key factors of the quantitative assessment of sustainability.

Design/Methodology/Approach. Critical analysis of the academic research works and reports of the official international organizations dedicated to the topic of energy consumption and $\mathrm{CO}_{2}$ emissions of HSR was conducted prior to the calculation of the above-mentioned indicators. The method of calculation based on International Union of Railways (UIC) was used in order to conduct the cluster analysis within the framework of current work. The main points considered are electricity consumption, carbon dioxide emissions, and level of passenger and freight demand. Statistical databases of UIC and International Energy Agency were used.
\end{abstract}

Findings. The calculations carried out by the authors of the given article demonstrate substantial figures of $\mathrm{CO}_{2}$ emissions intensity for Latvian section of the project related to the train load rate and traffic intensity which is evened out only by the $\mathrm{CO}_{2}$ emissions factor in Latvia.

Originality/Value/Practical implications. On this basis the authors present the directions for future research required for the development of the effective strategy for the Latvian Republic with the aim of achieving the increase in the RB project's ecological efficiency.

Keywords: Energy consumption; Environmental impact; Rail Baltica; Sustainable development.

JEL Classification: L98; Q51; R42.

\section{Introduction}

Nowadays, even though sustainable development is considered as focal point in a huge number of memorandums and strategies, the reality clearly envisages that the whole relationship between economic activity and environmental stability is based on the principles of net profit interests. This is clearly reflected in the fact that main strategic decisions being made in respect of the high-speed railway (HSR) network development have been formulated before the assessment of the environmental impact of such project.

The key factors for carrying out the quantitative assessment of sustainability are yet to be standardized. In addition, such factors are not considered to be mandatory for the purpose of infrastructure projects' evaluation. In case they are applied, more often than not, it is done in improper manner even though the minimum lifespan of the project is 30 years. Hence, the indicators used for such projects need to be linked to all long-term sustainable development strategies starting from the initial planning stage.

The carbon footprint caused by the construction of railway infrastructure is often ignored when considering the content of carbon in the transportation of passengers and cargo. Only in 2016 (UIC, 2016) a qualitative comparison of 10 existing methodologies was carried out. It was the first step to investigate how to develop a coordinated approach towards the inclusion of carbon dioxide $\left(\mathrm{CO}_{2}\right)$ emissions deriving from infrastructure construction, as well as the rolling stock production process and its further utilization at the end of the lifecycle, into the overall results of carbon efficiency assessment 
for the HSR project. As a result, it was suggested to include the embedded emissions of $\mathrm{CO}_{2}$ from the construction into the overall carbon intensity estimate in order to increase the transparency and consistency of the results.

At the same time, it was noted that density of the traffic is a key factor for the quick payback of emissions from infrastructure construction. Therefore, it is necessary to conduct a rigorous traffic assessment while planning a new railway infrastructure.

According to the official documents (i.e. Regulation (EU) No. 1316/2013 of the European Parliament and of the Council of 11 December 2013 establishing the Connecting Europe Facility, amending Regulation (EU) No. 913/2010 and repealing Regulations (EC) No. 680/2007 and (EC) No. 67/2010) of Rail Baltica (RB), it is emphasized that the common objective of the project is to develop it for the common good of the people, meaning that it has to be of a considerable strategic and economic importance to the EU citizens and economies.

HSR does not have the same characteristics across the regions. In the RB project, trainload indicators also vary depending on the region (Ernst \& Young Baltic, 2017). Yet, in the investment justification of the project, due attention was not paid to this aspect.

The purpose of this article is to determine the regional indicators of the energy consumption of the Latvian section of the RB project based on the analysis of the actual electricity supply ability, the pricing policy of Latvia and the potential traffic figures for this region.

For the analysis of energy consumption, the calculation method of International Union of Railways (UIC) was used. The calculation of the carbon footprint payback period from infrastructure construction and rolling stocks production is based on the technique which is similar to determining the time value of money, using discounting of the investment ratio for the project. Discounting was used on a simple basis, since the intensity of emissions from construction affects the environment significantly at present, and the positive effect of reducing emissions is too remote from the moment of construction to the lapse of time.

The study identifies the energy consumption level of the RB project for Latvia, the carbon efficiency of the project in the region, and puts forward recommendations on how to improve the project's conformity assessment in accordance with the requirements of sustainable development, as well as gives further research directions to clarify the project's passenger and cargo traffic flow.

The article is logically organized in five sections. The next section is literature review, in which different points of view of the ecological impact and carbon footprint of railway infrastructure, including HSR projects, by various specialists in the field and organizations concerned about the issue are illustrated. The third section highlights the methodology and other details of the research conducted for the purposes of identifying the energy consumption of the project and its ecological footprint. The next section presents the assessment results of energy consumption of the Latvian section of the RB project, illustrates the main determinants of the carbon footprint of this section of RB and presents the future trends. The conclusions are presented last.

\section{Literature Review}

In the majority of the reports issued by the European and international official entities, HSR is being considered as the most energy-efficient mode of transportation having the lowest environmental impact. However, the examples provided in these reports are usually taken either from a small part of the European projects with a high degree of air transportation replacement (United Kingdom-Paris) or from projects of Japan, Korea and China, which were implemented as a necessary tool for meeting the mobility needs of the population in the regions with high density.

At the same time, important factors leading to the success of these projects' implementation such as the use of cheap nuclear power for the operation and subsequently low carbon dioxide emission are mentioned only briefly. The comprehensive analysis of the results of the HSR project's construction, development and operation has not been presented yet. 
Anticipating the ex ante analysis of the energy consumption by the Latvian section of RB and its carbon footprint, it is advisable for the reader to become familiar with different research works conducted in the field. The authors did not focus on the analysis of the HSR projects performances in China due to the following reasons: the significant differences in many aspects of the HSR projects, such as the initial aim behind the projects together with the lack of the need for land acquisition, as well as the scale of construction, contributing to the standardization of the project documentation and the production of railway equipment and rolling stock.

In Garcia Alvarez and Cañizares (2010), the relationship between the speed of high-speed passenger trains, their energy consumption and greenhouse gas emissions is analysed. The authors compare the amounts of energy being consumed by the conventional and high-speed passenger rail systems. It is shown that, on average, high-speed rail systems consume 29 percent less energy than the conventional rail systems.

Jurado (2012) provides a detailed analysis of the energy consumption by trains in the Spanish HSR network, emphasizing that in many cases, rail services with low demand are installed without a vision of competitiveness or complementarity with other types of transport, which leads to a small traffic volume with an ever smaller number of passengers. In too many cases, lines of medium or low traffic offer trains with large capacity, when, on the contrary, it is necessary to increase the number of trains and reduce their individual capabilities.

In respect of carbon dioxide emissions, the previous research illustrated that $\mathrm{HSR} \mathrm{CO}_{2}$ emissions intensity varies between 4.0 and $32.9 \mathrm{~g} \mathrm{CO}_{2} / \mathrm{PKT}$ in the major European countries (Bueno et al 2016; Seguret, 2014).

The reason for difference in HSR $\mathrm{CO}_{2}$ emissions among the states is the variation in numbers of such parameters as occupancy levels and the source of train electricity. For example, the French HSR has low $\mathrm{CO}_{2}$ emissions per passenger-km (pkm) mainly due to the high share of nuclear power in French electricity supply to rail operators (Seguret, 2014). Nevertheless, there is a chance that investments into the rail industry may end up with much less environmental benefits than was expected during the stage of planning, because of several factors. It was argued by Miyoshi \& Givoni (2012) that the $\mathrm{CO}_{2}$ mitigation impact of possible HSR investments in the United Kingdom has become relatively minor in light of the low demand and the high current carbon intensity of electricity in that country is $0.5 \mathrm{~kg} \mathrm{CO} 2$ per $\mathrm{kWh}$. Their analysis shows relatively limited potential of HSR for reduction in $\mathrm{CO} 2$ emissions. In 2033, the overall $\mathrm{CO}_{2}$ reduction due to HST operation on the London-Manchester route is estimated at $100,000 \mathrm{t} \mathrm{CO}_{2}$ per annum, which is less than 0.1 percent of the total U.K. domestic transport emissions in 2007 . Thus, they demonstrate the train energy consumption $(21.45 \mathrm{kWh}$ per $\mathrm{km})$ in cases where the U.K. electricity carbon reaches intensity $\left(0.45 \mathrm{~kg} \mathrm{CO}_{2}\right.$ per $\left.\mathrm{kWh}\right)$.

In the research conducted by Von Rozycki et al. (2003) the $\mathrm{CO}_{2}$ emissions figures for German HSR network is much worse $(69.4 \mathrm{~g} / \mathrm{pkm})$, which can also be explained by the fact that the demand is relatively low with a very high level of $\mathrm{CO}_{2}$ emissions.

Another group of studies criticized the impact analyses of HSR systems for being focused solely on vehicle operation stage (Chester \& Horvath, 2009). The point of view taken up in these studies is that significant amount of energy use and $\mathrm{CO}_{2}$ emissions originates from non-operational aspects of HSR systems, such as construction of stations and infrastructure in general, manufacturing of the vehicles, its maintenance and fuel production. The conclusion is based on a comprehensive life-cycle energy and emissions inventory of different modes of transportation and indicates the fact that the operational energy use and $\mathrm{CO}_{2}$ emissions of rail systems are nearly two times less than the non-operational one.

Westin \& Kageson (2012) went even further in their conclusions on ecological benefits of HSR:

To be able to balance the annualized emissions from the construction of the line, traffic volumes need to be large, and the diverted traffic should primarily come from aviation. An important aspect that was disregarded in the considerable number of researches conducted is the time lag between construction and the years when its emissions will gradually be paid back. Even if emissions from the construction are balanced in the longer term by reduced emissions from traffic, they do have a short-term impact on the atmospheric concentration of greenhouse gases. There is thus an obvious risk that investing in high 
speed rail will add to the difficulties of keeping the atmospheric content of greenhouse gases at a level that prevents the mean global temperature from exceeding its pre-industrial level by more than 2 degrees Celsius.

The research by Bueno et al. (2016) also shows that even in the most optimistic scenarios, the reduction in emissions from a modal transition from other modes of transport will not compensate $\mathrm{CO}_{2}$ emissions associated with the construction of HSR infrastructure and its operation $\left(2.71 \mathrm{Mt} \mathrm{CO}_{2}\right)$, and it will not contribute to the net energy savings of up to 55 years of operation. As an example, the research provides the figures available after the calculation of $\mathrm{CO}_{2}$ emissions and reduction of energy consumption over the life of HSR infrastructure (60 years) in the Basque region. The validity of these results suggests that reducing carbon dioxide emissions and energy savings should not be used as a general argument for investing in high-speed rail infrastructure.

In the report provided by Jehanno (2011), the emissions from the construction of the high-speed rail lines were estimated. In the range of $58 \mathrm{t}-176 \mathrm{t}$ of $\mathrm{CO}_{2}$ per $\mathrm{km}$ of line and year. Lines with a moderate space and relief constraints (for example in France) emits around 60t of $\mathrm{CO}_{2}$. By comparison, the carbon footprint of the construction of a $2 \times 3$ lane motorway is $73 \mathrm{t} \mathrm{CO}_{2}$ (with similar transport capacity under the same geographical conditions)... The construction, maintenance and disposal of the rolling stock lead to emissions of $0.8 \mathrm{CO}_{2}$ to $1.0 \mathrm{~g} \mathrm{CO}_{2}$ per pkm. Compared with the construction of a car $(20.9 \mathrm{~g}$ $\left.\mathrm{CO}_{2} / \mathrm{pkm}\right)$, the construction of a HSR-Train is 20 times lower. The construction of an airplane $(0.5 \mathrm{~g}$ $\mathrm{CO}_{2} / \mathrm{pkm}$ ) is in the same order of magnitude as HSR.

However, all the researchers agree on one thing: in order to reduce the emissions and increase the energy efficiency of the HSR, it is necessary to extend the passenger and cargo traffic to the maximum capacity by attracting riders from air travel, use of cleaner electricity sources and comprehensive planning. The plan of operation for the existing railway system has to be considered as well, because it will be subjected to partial substitution by the newly created one.

Considering the RB project, it is important to mention the lack of research works available, which include analysis of the energy consumption and $\mathrm{CO}_{2}$ emissions of the future project. Only Humal et al. (2018) have noticed that authors of the investment justification have ignored the requirement of 'Guide to Cost-Benefit Analysis' (EC, 2014) regarding the $\mathrm{CO}_{2}$ emissions arising out of the project's new infrastructure construction.

According to the authors of this article, the discussion of this issue had to start in advance, because at the present moment two out of the three state participants in the project import electricity rather than generate it. Furthermore, new large power plants are not planned to be built in this region preceding the start of RB operation.

\section{Methodology}

The methodological scheme of the given study for the Latvian section of RB consists of three major steps which include the determination of

1. energy consumption and emissions from passenger flows (Ernst \& Young Baltic, 2017) scenario;

2. energy consumption and emissions from freight flows (Ernst \& Young Baltic, 2017) scenario;

3. total energy consumption and emissions, including annualized emissions from infrastructure construction.

The total amount of $\mathrm{CO}_{2}$ emissions will be an amount of the required reduction of emissions from other modes of transport, cargo and passengers, which will have to switch to a new railway.

In case of further research, the results of this study can serve as the boundary indicators of the net environmental effect of the RB project for the Latvian section of the route.

The study uses these definitions (Union of Railways, 2012):

- One train-km is one train travelling for $1 \mathrm{~km}$. Total train- $\mathrm{kms}$ are calculated by multiplying the number of trains by the number of $\mathrm{km}$ they travel. 
- One gross tkm (tonne-km) is 1 tonne (including weight of wagons, locomotives and cargo) travelling for $1 \mathrm{~km}$. The gross tkm of one train is calculated by multiplying the total weight of the train by the distance it travels.

- One seat-km is one seat travelling for $1 \mathrm{~km}$, calculated by multiplying the number of seats in a train by the distance travelled.

- One passenger-km (pkm) is one passenger travelling for $1 \mathrm{~km}$. The number of pkm is the number of passengers multiplied by the distance travelled per passenger.

- Occupancy (loading) factor is the relation between the number of places occupied and the maximum number of places offered. It can be calculated by dividing the passenger-km by the seat-km.

- Average electricity use pass $(\mathrm{kWh} / \mathrm{seat}-\mathrm{km})$ is the required amount of energy to transfer one seat travelling for $1 \mathrm{~km}$. This indicator was considered by Jehanno (2011), Jurado (2012) and IEA \& UIC (2017) based on the electric consumption of an Alstom AGV (0.033 kWh/seat-km).

- $\mathrm{CO}_{2}$ emission factor of traction electricity is the well-to-wheel $\mathrm{CO}_{2}$ emission factor of the electricity used by railway (in $\mathrm{kg} \mathrm{CO}_{2}$-eq/kWh). In this study, this indicator is assumed to be equal to the country coefficient, due to the lack of data on future electricity suppliers for the project. Detailed information on the methodologies, assumptions and data sources, as well as recommendations, for using this factor is found in Koffi et al. (2017).

Energy consumption of freight transport is influenced by logistical, technical and operational factors. Energy consumption per tkm is strongly related to the maximum net tons carried. Total consumption relates to the vehicle's mass because almost all the energy losses of the vehicle (rolling resistance, aerodynamics, gravity and kinetic energy) depend on the vehicle tare.

In estimating the energy consumption of freight flows of Latvian RB section, supposedly representative average values are used (with many limitations).

It should be noted that the calculated values of some indicators of freight rail transport presented in global surveys of international organizations often do not correspond to the primary statistical country data or regional research data. Hence IEA ETSAP (2011) estimates global averages for carbon intensity of freight rail to be 15 to $40 \mathrm{~g} \mathrm{CO}_{2}$-eq/tkm (compared with 190-300 $\mathrm{g} \mathrm{CO}_{2}$-eq/tkm for long distance trucking), whereas, according to the methodology proposed in García Álvarez et al. (2013), electric trains are overall as efficient as megatrucks $((0.05 \mathrm{kWh} / \mathrm{tkm}$ and $13 \mathrm{~g} \mathrm{CO} / \mathrm{tkm}) \mathrm{vs} .(0.28 \mathrm{kWh} / \mathrm{tkm}$ and $73 \mathrm{~g} \mathrm{CO}_{2} / \mathrm{tkm}$ ) over flat profiles. This author's data is taken as the average value of the electric power consumption for freight trains of the Latvian RB section.

In Europe there is a lack of data which describe the trend of energy consumption in the freight sector. EuroStat, one of the largest collectors of those sorts of data, has no such detailed (split) data available as yet.

Electricity consumption and $\mathrm{CO}_{2}$ emissions for passengers traffic according to the location-based method of the GHG Protocol Scope 2 Guidance are calculated using the following equations:

Annual Electricity Use $=$ Avg. Electricity Use $\times$ Train Capacity $\times$ Line Length $\times 365 \times$ Number of train/day

$[\mathrm{kWh}]=[\mathrm{kWh} / \mathrm{seat}-\mathrm{km}] \times[$ seats $] \times[\mathrm{km}]$

Annual $\mathrm{CO}_{2 \mathrm{eq}}$ Emissions $=$ Annual Electricity Use $\times \mathrm{CO}_{2 \mathrm{eq}}$ Emissions Factor

$\left[\mathrm{kt} \mathrm{CO}_{2 \mathrm{eq}}\right]=[\mathrm{kWh}] \times\left[\mathrm{kg} \mathrm{CO} \mathrm{COq}_{2 \mathrm{kWh}} / 10^{6}\right.$

Electricity Intensity = Avg. Electricity Use/Occupancy

$[\mathrm{kWh} / \mathrm{pkm}]=[\mathrm{kWh} / \mathrm{seat}-\mathrm{km}] /[\%]$ 
$\mathrm{CO}_{2}$ Emissions Intensity $=$ Electricity Intensity $\times \mathrm{CO}_{2}$ Emissions Factor

$\left[\mathrm{g} \mathrm{CO}_{2 \text { eq }} \mathrm{pkm}\right]=[\mathrm{kWh} / \mathrm{pkm}] \times\left[\mathrm{kg} \mathrm{CO} \mathrm{Ceq}_{2 \mathrm{kWh}} / 10^{3}\right.$

The production data collected regarding Latvian RB are given in Tables 1 and 2.

Table 1. Passenger flow data (Source: Ernst \& Young Baltic, 2017; Koffi et al. 2017; Jehanno, 2011; Jurado, 2012; IEA \& UIC, 2017)

\begin{tabular}{|c|c|c|c|c|}
\hline \multicolumn{2}{|l|}{ Indicators of RB } & Unit & Total section & Riga-RIX \\
\hline \multicolumn{2}{|l|}{ Line length } & $\mathrm{km}$ & 262.42 & 13.3 \\
\hline \multicolumn{2}{|l|}{ Number of trains } & Pairs/day & 8 & 36 \\
\hline \multicolumn{2}{|l|}{ Train capacity } & Seat & 402 & 228 \\
\hline \multicolumn{2}{|l|}{ Passenger flow } & Thous. pass & & \\
\hline \multirow{2}{*}{2026} & Base case & & 869 & 1852 \\
\hline & Low case & & 690 & 1470 \\
\hline \multirow{2}{*}{2035} & Base case & & 930 & 2085 \\
\hline & Low case & & 734 & 1643 \\
\hline \multirow{2}{*}{2045} & Base case & & 991 & 2347 \\
\hline & Low case & & 780 & 1841 \\
\hline \multirow{2}{*}{2055} & Base case & & 1050 & 2628 \\
\hline & Low case & & 826 & 2056 \\
\hline \multicolumn{2}{|l|}{ Average electricity use } & $\mathrm{kWh} /$ seat-km & 0.033 & 0.033 \\
\hline \multicolumn{2}{|c|}{$\begin{array}{l}\text { Emissions factor for electricity consumption } \\
\text { (LCA approach) }\end{array}$} & $\mathrm{kg} \mathrm{CO} 2 \mathrm{eq} / \mathrm{kWh}$ & 0.183 & 0.183 \\
\hline
\end{tabular}

LCA, life circle assessment.

Electricity consumption and $\mathrm{CO}_{2}$ emissions for cargo traffic according to the location-based method of the GHG Protocol Scope 2 Guidance are calculated using the following equations:

Annual Electricity Use $=$ Avg. Electricity Use $\times$ Train Capacity $\times$ Line Length $\times 365 \times$ Number of train/day

$[\mathrm{kWh}]=[\mathrm{kWh} / \mathrm{tkm}] \times[$ tonnes $] \times[\mathrm{km}]$

Annual $\mathrm{CO}_{2 e q}$ Emissions = Annual Electricity Use $\times \mathrm{CO}_{2 e q}$ Emissions Factor

$\left[\mathrm{kt} C O_{2 e q}\right]=[\mathrm{kWh}] \times\left[\mathrm{kg} C O_{2 e q} / \mathrm{kWh}\right] / 10^{6}$

Electricity Intensity $=$ Avg. Electricity Use/Loading

$[\mathrm{kWh} / \mathrm{km}]=[\mathrm{kWh} / \mathrm{tkm}] /[\%]$

$\mathrm{CO}_{2 e q}$ Emissions Intensity $=$ Electricity Intensity $\times \mathrm{CO}_{2 e q}$ Emissions Factor

$\left[\mathrm{g} C \mathrm{O}_{2 e q} / \mathrm{tkm}\right]=[\mathrm{kWh} / \mathrm{tkm}] \times\left[\mathrm{kg} C O_{2 e q} / \mathrm{kWh}\right] / 10^{3}$ 
Table 2. Freight flow data (Source: Ernst \& Young Baltic, 2017; Koffi et al. 2017; Jehanno, 2011; Jurado, 2012; IEA \& UIC, 2017)

\begin{tabular}{|c|c|c|c|c|}
\hline \multirow{2}{*}{\multicolumn{2}{|c|}{ Indicators of $\mathbf{R B}$}} & \multirow[b]{2}{*}{ Unit } & \multicolumn{2}{|c|}{ Total Latvian section } \\
\hline & & & $\begin{array}{c}\text { Border EST- } \\
\text { Salaspils }\end{array}$ & $\begin{array}{l}\text { Salaspils- } \\
\text { Border LT }\end{array}$ \\
\hline \multicolumn{2}{|c|}{ Line length } & $\mathrm{km}$ & 126 & 77.4 \\
\hline \multicolumn{2}{|c|}{ Freight train capacity, net } & Tonnes & 1098 & 1098 \\
\hline \multicolumn{2}{|c|}{ Average electricity use } & $\mathrm{kWh} / \mathrm{tkm}$ & 0.05 & 0.05 \\
\hline \multicolumn{2}{|c|}{$\mathrm{CO}_{2 \text { eq }}$ emission factor } & $\mathrm{kg} \mathrm{CO} 2 \mathrm{eq} / \mathrm{kWh}$ & 0.183 & 0.183 \\
\hline \multicolumn{2}{|c|}{ Number of trains } & Pairs/day & & \\
\hline \multirow{2}{*}{2026} & Base case & & 1 & 2 \\
\hline & Low case & & 1 & 1 \\
\hline \multirow{2}{*}{2027} & Base case & & 2 & 3 \\
\hline & Low case & & 2 & 2 \\
\hline \multirow{2}{*}{2028} & Base case & & 4 & 5 \\
\hline & Low case & & 3 & 3 \\
\hline \multirow{2}{*}{2029} & Base case & & 6 & 9 \\
\hline & Low case & & 5 & 8 \\
\hline \multirow{2}{*}{2030} & Base case & & 9 & 10 \\
\hline & Low case & & 7 & 9 \\
\hline \multirow{2}{*}{2040} & Base case & & 11 & 13 \\
\hline & Low case & & 9 & 11 \\
\hline \multirow{2}{*}{2050} & Base case & & 12 & 15 \\
\hline & Low case & & 10 & 12 \\
\hline
\end{tabular}

The data on the distribution of carbon dioxide emissions by years of operation arising during the construction of the railway infrastructure were adopted by the authors on the basis of the report (UIC, 2016). For corridors that have a share of tunnels and bridges below $30 \%$, a common, conservative and realistic value of around 50-70 $\mathrm{tCO}_{2} / \mathrm{km} /$ year would be adopted following the values and the results using the IFEU/Tuschchmid methodology; on a case by case basis, lower emission factors could be used if railway operators could justify such lower values.

However, due to the fact that, according to this methodology, the emissions are distributed by linear depreciation, the authors of the study conducted a procedure for compounding the built-in $\mathrm{CO}_{2}$ emissions at construction at a rate of 5 percent, similar to the socio-economic discount rate of 5 percent adopted in the investment rationale for the project. 


\section{Results}

The results of the calculations presented below are based on the methodology described in the previous section.

Table 3 shows the results of the electricity consumption assessment, $\mathrm{CO}_{2}$ emissions of the passenger traffic flow in the Latvian section of RB and their intensity according to the periods referred to in the investment justification of the project.

Table 3. Performance of passenger flow on the Latvian section of RB (Source: author's compilation)

\begin{tabular}{|c|c|c|c|c|c|c|c|c|}
\hline \multirow[b]{2}{*}{ Perspective } & \multicolumn{4}{|c|}{ Total section } & \multicolumn{4}{|c|}{ Riga-RIX } \\
\hline & $\begin{array}{c}\text { Annual } \\
\text { Electricity } \\
\text { use, } \\
\text { MWh/year }\end{array}$ & $\begin{array}{c}\text { Annual } \\
\mathbf{C O}_{2 \mathbf{e q}} \\
\text { emissions } \\
\mathrm{kt} \\
\mathrm{CO}_{2 \mathrm{eq}} / \text { year }\end{array}$ & $\begin{array}{c}\text { Electricity } \\
\text { use per } 1 \\
\text { pkm, kWh }\end{array}$ & $\begin{array}{c}\mathbf{C O}_{2 \mathrm{eq}} \\
\text { emissions } \\
\text { intensity, } \\
\mathrm{g} \mathrm{CO}_{2 \mathrm{eq}} / \mathrm{pk} \\
\mathrm{m}\end{array}$ & $\begin{array}{c}\text { Annual } \\
\text { Electricity } \\
\text { use, } \\
\text { MWh/year }\end{array}$ & $\begin{array}{c}\text { Annual } \\
\mathrm{CO}_{2 \mathbf{e q}} \\
\text { emission } \\
\text { s, kt } \\
\mathrm{CO}_{2 \mathrm{eq}} / \mathrm{ye} \\
\text { ar }\end{array}$ & $\begin{array}{c}\text { Electrici } \\
\text { ty use } \\
\text { per } 1 \\
\text { pkm, } \\
\text { Wh }\end{array}$ & $\begin{array}{c}\mathrm{CO}_{2 \mathrm{eq}} \\
\text { emissions } \\
\text { intensity, } \\
\mathrm{g} \\
\mathrm{CO}_{2 \mathrm{eq}} / \mathrm{pk} \\
\mathrm{m}\end{array}$ \\
\hline Base case & 20330.6 & 3720.5 & 0.089 & 16.31 & 2629.8 & 481.3 & 0.107 & 19.54 \\
\hline Low case & 20330.6 & 3720.5 & 0.112 & 20.55 & 2629.8 & 481.3 & 0.135 & 24.62 \\
\hline Base case & 20330.6 & 3720.5 & 0.083 & 15.24 & 2629.8 & 481.3 & 0.095 & 17.35 \\
\hline Low case & 20330.6 & 3720.5 & 0.106 & 19.32 & 2629.8 & 481.3 & 0.120 & 22.02 \\
\hline Base case & 20330.6 & 3720.5 & 0.078 & 14.31 & 2629.8 & 481.3 & 0.084 & 15.42 \\
\hline Low case & 20330.6 & 3720.5 & 0.099 & 18.18 & 2629.8 & 481.3 & 0.107 & 19.65 \\
\hline Base case & 20330.6 & 3720.5 & 0.074 & 13.50 & 2629.8 & 481.3 & 0.075 & 13.77 \\
\hline Low case & 20330.6 & 3720.5 & 0.094 & 17.16 & 2629.8 & 481.3 & 0.096 & 17.60 \\
\hline
\end{tabular}

Based on the calculations provided above, it can be concluded that passenger traffic in the Latvian section of the RB highway has a low energy efficiency level. Energy intensity of one pkm in the first year of entering the railway operation is $89 \mathrm{Wh}$ in the baseline scenario and $112 \mathrm{Wh}$ in the low demand scenario. The intensity of carbon dioxide emissions in the same period will be 16.31 and $20.55 \mathrm{~g} \mathrm{CO}_{2}-$ eq/pkm, respectively.

These indicators are somewhat in the middle of the HSR emission intensity range for the EU as a whole. Yet, it is necessary to take into account that Latvia's emissions factor is one of the lowest in Europe and, mainly due to that factor, the emission intensity in the Latvian section of RB does not exceed European indicators (Bueno et al. 2016; IEA \& UIC, 2017).

However, if we compare the results obtained with the emission rate indicator in the Lithuanian section of RB in the first year of operation $\left(6.6 \mathrm{~g} \mathrm{CO}_{2}-\mathrm{eq} / \mathrm{pkm}\right)$, then it becomes obvious that low passenger demand for highway services in Latvia creates a significant negative environmental effect.

The results (Table 3) also show the emissions generated by the shuttle to Riga Airport (RIX). Due to the need for high frequency of traffic, train load will be not more than 18 percent, which leads to an increase in $\mathrm{CO}_{2}$ emissions in this area to $481.3 \mathrm{kt} \mathrm{CO}_{2}$-eq/year in the first year of operation. It should be noted that all the airplanes of Air Baltic for 2017 created less $\mathrm{CO}_{2}$ emissions - $321 \mathrm{kt} \mathrm{CO}_{2}$ (AIR BALTIC 
CORPORATION, 2017) - than a $13.3 \mathrm{~km}$ railway section from the centre of Riga to the airport would create.

The calculations of electricity consumption, $\mathrm{CO}_{2}$ emissions of freight flows in the Latvian sector of $\mathrm{RB}$, as well as their intensity over the periods specified in the investment justification of the project, are given in Table 4.

Table 4. Performance of freight flows on the Latvian section of RB (Source: author's compilation)

\begin{tabular}{|c|c|c|c|c|c|c|c|c|c|}
\hline \multirow{2}{*}{\multicolumn{2}{|c|}{ Perspective }} & \multicolumn{4}{|c|}{ Border Estonia-Salaspils } & \multicolumn{4}{|c|}{ Salaspils - -Border Lithuania } \\
\hline & & $\begin{array}{c}\text { Annual } \\
\text { Electricity } \\
\text { use, MWh/ } \\
\text { year }\end{array}$ & $\begin{array}{c}\text { Annual } \\
\mathbf{C O}_{2 \mathrm{eq}} \\
\text { emissions, } \\
\mathrm{kt} \mathrm{CO}_{2 \mathrm{eq}} / \text { year }\end{array}$ & $\begin{array}{c}\text { Electricity } \\
\text { use per } 1 \\
\text { tkm, KkWh }\end{array}$ & $\begin{array}{c}\mathrm{CO}_{2 \mathrm{eq}} \\
\text { emissions } \\
\text { intensity, } \\
\mathrm{gCO}_{2 \mathrm{eq}} \\
/ \mathrm{tkm}\end{array}$ & $\begin{array}{c}\text { Annual } \\
\text { Electricity } \\
\text { Use, MWh/ } \\
\text { year }\end{array}$ & $\begin{array}{c}\text { Annual } \\
\text { CO }_{2 \text { eq }} \\
\text { emissions, } \\
\text { kt } \mathrm{CO}_{2 \mathrm{eq}} \\
\text { /year }\end{array}$ & $\begin{array}{l}\text { Electricity } \\
\text { use per } 1 \\
\text { tkm, Wh }\end{array}$ & $\begin{array}{c}\mathrm{CO}_{2 \mathrm{eq}} \\
\text { emissions } \\
\text { intensity, } \\
\mathrm{g} \mathrm{CO}_{2 \mathrm{eq}} \\
\text { /tkm }\end{array}$ \\
\hline \multirow{2}{*}{2026} & Base case & 5049.7 & 924.1 & 0.057 & $10, .48$ & 6203.9 & 1135.3 & 0.100 & 18.34 \\
\hline & Low case & 5049.7 & 924.1 & 0.067 & 12.23 & 3101.9 & 567.7 & 0.057 & 10.43 \\
\hline \multirow{2}{*}{2027} & Base case & 10099.4 & 1848.2 & 0.057 & $10, .48$ & 9305.8 & 1703.0 & 0.071 & 12.99 \\
\hline & Low case & 10099.4 & 1848.2 & 0.073 & 13.33 & 6203.9 & 1135.3 & 0.057 & 10.43 \\
\hline \multirow{2}{*}{2028} & Base case & 20198.8 & 3696.4 & 0.073 & 13.33 & 15509.7 & 2838.3 & 0.077 & 14.10 \\
\hline & Low case & 15149.1 & 2772.3 & 0.071 & 12.94 & 9305.8 & 1703.0 & 0.057 & 10.48 \\
\hline \multirow{2}{*}{2029} & Base case & 30298.2 & 5544.6 & 0.063 & 11.58 & 27917.6 & 5108.9 & 0.080 & 14.67 \\
\hline & Low case & 25248.5 & 4620.5 & 0.067 & 12.22 & 18611.7 & 3406.0 & 0.089 & 16.30 \\
\hline \multirow{2}{*}{2030} & Base case & 45447.3 & 8316.9 & 0.077 & 14.04 & 31019.5 & 5676.6 & 0.067 & 12.22 \\
\hline & Low case & 35347.9 & 6468.7 & 0.074 & 13.51 & 27917.6 & 5108.9 & 0.080 & 14.67 \\
\hline \multirow{2}{*}{2035} & Base case & 45447.3 & 8316.9 & 0.062 & 11.38 & 31019.5 & 5676.6 & 0.057 & 10.48 \\
\hline & Low case & 35347.9 & 6468.7 & 0.061 & 11.16 & 27917.6 & 5108.9 & 0.064 & 11.79 \\
\hline \multirow{2}{*}{2040} & Base case & 55546.7 & 10165.1 & 0.074 & 13.46 & 37223.5 & 6811.9 & 0.069 & 12.71 \\
\hline & Low case & 45447.3 & 8316.9 & 0.074 & 13.46 & 34121.5 & 6244.2 & 0.069 & 12.71 \\
\hline \multirow{2}{*}{2050} & Base case & 60596.4 & 11089.1 & 0.074 & 13.46 & 46529.3 & 8514.9 & 0.069 & 12.71 \\
\hline & Low case & 50497.1 & 9241.0 & 0.074 & 13.46 & 37223.5 & 6811.9 & 0.069 & 12.71 \\
\hline
\end{tabular}

As presented in Table 4, freight traffic indicators for the Latvian section of RB are more efficient than for passenger traffic: the energy intensity of $1 \mathrm{tkm}$ and the emission intensity will be $57 \mathrm{Wh}$ and 10.48 $\mathrm{g} \mathrm{CO}_{2}-\mathrm{eq} / \mathrm{tkm}$, respectively, in the first year of operation of the project.

After the year 2035, upon reaching the estimated maximum load on the whole section of the Latvian part of RB, the above figures, on average, will constitute $59 \mathrm{Wh}$ and $10.94 \mathrm{~g} \mathrm{CO}_{2}$-eq/tkm, respectively. 
It is possible that the project management will still reconsider its views on the combination of passenger and freight traffic in the Latvian section and will consider the possibility of replacing part of passenger traffic by freight or introducing regional passenger trains to replace part of high-speed trains going all over the main line. This would improve both the energy characteristics of the project and the environmental ones. The change in the proportions of the total volume of the organization of traffic on high-speed highways, as one of the strategies for increasing the energy efficiency of HSR, was proposed (Akerman, 2011) for Sweden.

On the basis of the presented calculations, the conclusion regarding the energy intensity of the project of the new railway line could be drawn. The total need for electricity for the Latvian section of the RB can range from $34.2 \mathrm{GWh}$ in 2026 to $130.1 \mathrm{GWh}$ in 2050 and beyond.

Table 5. IEA Key Indicators for Latvia (Source: IEA ,2017)

\begin{tabular}{lc}
\hline \multicolumn{1}{c}{ Indicator } & Latvia \\
\hline Electricity generation, by fuel, GWh & 2944 \\
Gas & 823 \\
Biofuels & 2530 \\
Hydro & 128 \\
Wind & 6425 \\
Total & 6.98 \\
Electricity consumption, TWh & -0.56 \\
Deficit (-)/surplus (+), TWh & 1.6 \\
$\mathrm{CO}_{2 \mathrm{eq}}$ intensity of energy mix, $\mathrm{t} \mathrm{CO}{ }_{2 \mathrm{eq}} / \mathrm{t} \mathrm{OE}$ & 3.47 \\
$\mathrm{CO}_{2 \mathrm{eq}}$ emissions per capita, $\mathrm{CO} \mathrm{Ceq}_{2 \mathrm{capita}}$ & 0.093 \\
Electricity prices for industry, Euro/kWh & \\
\hline
\end{tabular}

As can be seen (Table 5), already in 2017, electricity consumption in Latvia exceeded production by $560 \mathrm{GWh}$. Therefore, the issue of power supply of a project with high energy intensity (approximately 2 percent of the total energy consumption of Latvia) should now be addressed at the state level.

Infrastructure manager maintenance costs for traction costs are assumed (adopted from Atkins 'Rail Baltica Cost Estimation, Renewal \& Maintenance and Benchmarking' study, 2017) to be the following: $15538 \mathrm{EUR} / \mathrm{km} / \mathrm{year}$ from total operating expenses of $69402 \mathrm{EUR} / \mathrm{km} / \mathrm{year}$. That is, the cost of electricity will be more than 20 percent in the operating costs of the project.

It should be borne in mind that in Latvia electricity prices are the highest among all the project member states. Furthermore, over the last 5 years, Latvia has been experiencing a rise in electricity prices, even though, most of the energy sources are renewable, which means the cost of production should be quite low. This tendency appears to be odd in comparison to a steady decline in electricity prices in Lithuania and Estonia. 
Such a high component of the share of electricity costs, combined with a high price for it in Latvia, can lead to an even greater drop in demand for passenger services for the RB project in the Latvian section.

General results of $\mathrm{CO}_{2}$ emissions calculations are presented in Table 6.

Table 6. Total $\mathrm{CO}_{2}$ emissions level of the Latvian RB section (Source: author's compilation)

\begin{tabular}{|c|c|c|c|c|c|}
\hline \multicolumn{2}{|c|}{ Perspective } & \multirow{2}{*}{$\frac{\begin{array}{c}\text { Emissions from } \\
\text { constructions, } \mathrm{kt} \\
\mathrm{CO}_{2 \mathrm{eq}} / \text { year }\end{array}}{16.5}$} & \multirow{2}{*}{$\begin{array}{c}\begin{array}{c}\text { Emissions from } \\
\text { passenger flows, } \\
\text { kt } \mathrm{CO}_{2 \mathrm{eq}} / \text { year }\end{array} \\
4201.8\end{array}$} & \multirow{2}{*}{$\begin{array}{c}\begin{array}{c}\text { Emissions from } \\
\text { freight flows, } \\
\mathrm{kt} \mathrm{CO}_{2 \mathrm{eq}} / \mathrm{year}\end{array} \\
2059.41\end{array}$} & \multirow{2}{*}{$\begin{array}{c}\begin{array}{c}\text { Total, } \\
\mathrm{kt} \mathrm{CO}_{2 \text { eq }} / \mathrm{year}\end{array} \\
\frac{6277.69}{}\end{array}$} \\
\hline & Base case & & & & \\
\hline 2020 & Low case & 16.5 & 4201.8 & 1491.75 & 5710.03 \\
\hline \multirow{2}{*}{2030} & Base case & 20.1 & 4201.8 & 13993.45 & 18215.29 \\
\hline & Low case & 20.1 & 4201.8 & 11577.60 & 15799.44 \\
\hline \multirow{2}{*}{2035} & Base case & 25.6 & 4201.8 & 13993.45 & 18220.84 \\
\hline & Low case & 25.6 & 4201.8 & 11577.60 & 15804.99 \\
\hline \multirow{2}{*}{2040} & Base case & 32.7 & 4201.8 & 16976.95 & 21211.43 \\
\hline & Low case & 32.7 & 4201.8 & 14561.10 & 18795.58 \\
\hline \multirow{2}{*}{2050} & Base case & 41.8 & 4201.8 & 19604.03 & 23847.54 \\
\hline & Low case & 41.8 & 4201.8 & 16052.86 & 20296.37 \\
\hline
\end{tabular}

The results (Table 6) are the starting point for the subsequent calculations of the environmental effects of the new railway line that results from the modal replacement. The level of modal replacement needs to be specified in accordance with several governmental programmes for the development of more sustainable road transport infrastructure. Moreover, it is necessary to determine the induced demand for the services of the new highway and take into account the need for the state to finance the transport infrastructure, which will supply the new highway with the cargo and passenger flow, maintaining it in proper condition.

\section{Conclusions}

The purpose of this research was to assess the energy consumption and $\mathrm{CO}_{2}$ emissions of the Latvian section of RB project in order to be able to evaluate the environmental contribution of the project in ensuring sustainable mobility.

The information provided in this research allows us to draw several conclusions. First, the Latvian section of the RB highway will require to supply the line with a maximum share of generation from renewable sources or import electricity from nuclear power plants to ensure a low proportion of the cost of electricity in the total operating costs, hence in the tariffs for services. For instance, in Poland a number of nuclear powers are expected to be built by the time the operation of RB starts.

In addition, the use of low-emission electric power will minimize the total $\mathrm{CO}_{2}$ emissions in the event of low demand for line services in the first years of its operation. 
The second important conclusion is that in order to assess whether there will be a significant reduction in emissions from a modal shift from regimes with a higher environmental impact, it is important to conduct a proper life circle assessment using the IFEU/Tuchschmid methodology recommended by UIC. It needs to be done in order to consider not only the operational period, but also the period of construction, maintenance and disposal of $\mathrm{RB}$, which was not done in the investment justification of the project, despite the requirements of the 'Guide to Cost-Benefit Analysis of Investment Projects. Economic appraisal tool for Cohesion Policy 2014-2020'.

This would allow monitoring the carbon footprint already at the stage of procurement of construction works and equipment for the project. Applying a scientific approach and creating a financial incentive would reduce carbon emissions at the construction stage by allocating part of the budget for the construction of RB infrastructure for the purpose of reducing emissions.

Existing carbon arbitrage funds are already offering a powerful incentive to reduce the carbon content of the infrastructure using the most cost-effective solutions.

The introduction of the procurement requirement for low $\mathrm{CO}_{2}$ emissions in the proposed works and equipment, as well as the encouragement to use carbon arbitration funds during construction, will allow Latvian representatives interested in the development of the project to play a leading role in discussing sustainability and environmental issues of the RB. It will also encourage other project participants to use the tools for the improvement of environmental performance of the new railway line.

One of the directions of future research determined by the results of this work will be the determination of the induced demand for RB services and the variables on which it depends. The investment rationale for the project states that the induced demand is 0 percent throughout the project. On the one hand, this has improved the environmental performance of the project, but on the other hand, this assumption creates high risks of not loading a new line. Furthermore, the awareness of the percentage of new cargo traffic is important for an adequate assessment of both energy consumption and $\mathrm{CO}_{2}$ emissions, because the energy required for the transportation of new passengers and cargo represents a net increase in energy demand, which partially reduces the benefits derived from the modal transition from road and air transport.

In this context, arguments regarding energy that are put forward in favour of investment in RB may already be controversial: RB can both contribute to sustainable mobility through a major transition from road and air transport to rail, but it can also increase overall mobility, which will result in the net effect being negative.

\section{References}

Akerman, J. (2011). "The role of high-speed rail in mitigating climate change - the Swedish case Europabanan from a life cycle perspective”, Transportation Research Part D: Transport and Environment, 16, pp. $208-217$. https://doi.org/10.1016/j.trd.2010.12.004

Annual emissions report AIR BALTIC CORPORATION. (2017). [Accessed 02.04.2019]. Available from Internet:http://www.caa.lv/upload/userfiles/files/AirBaltic\%20emisiju\%20zinojums\%20par\%202017_gadu.pdf

Bueno, G., Hoyos, D., \& Capellán-Pérez, I. (2016). Contribución del proyecto de Y vasca a la reducción del consumo de energía y a la lucha contra el cambio climático. Cuadernos de Trabajo/Lan Koadernoak Hegoa, Universidad del País Vasco/Euskal Herriko Unibertsitatea UPV/EHU. [Accessed 14.07.2018]. Available from Internet:

http://biblioteca.hegoa.ehu.es/downloads/20304/\%2Fsystem\%2Fpdf\%2F3772\%2FLan_Koadernoa 71.pdf

Chester, M., \& Horvath, A.(2009). Environmental assessment of passenger transportation should include infrastructure and supply chains. Environmental Research Letters, 4:024008. DOI:10.1088/1748-9326/4/2/024008

Ernst \& Young Baltic. (2017). Rail Baltica Global Project. Cost-Benefit Analysis, Final Report. [Accessed 24.04. 2017]. Available at: http://railbaltica.org/wp-content/uploads/2017/04/RB_CBA_FINAL_REPORT.pdf

European Commission Directorate-General for Regional and Urban policy.(2014). Guide to Cost-Benefit Analysis of Investment Projects. Economic appraisal tool for Cohesion Policy 2014-2020. [Accessed 10.04.2019]. Available from Internet: https://ec.europa.eu/inea/sites/inea/files/cba_guide_cohesion_policy.pdf 
García Álvarez, A., Perez-Martinez, P. J. \& Gonzalez-Franco, I.(2013). Energy Consumption and Carbon Dioxide Emissions in Rail and Road Freight Transport in Spain: A Case Study of Car Carriers and Bulk Petrochemicals. [Accessed 07.12.2017]. Available from Internet: http://oa.upm.es/22486/1/INVE_MEM_2013_152479.pdf

García Álvarez, A.(2013). Análisis sistemático del consumo energético en líneas ferroviarias metropolitanas, de cercanías y de alta velocidad, con valoración del impacto energético y del resultado económico, incluyendo el desarrollo y contraste de modelos y simuladores parametrizables (ELECRAIL). Fundación de los Ferrocarriles Españoles. [Accessed 04.04.2019]. Available from https://trimis.ec.europa.eu/sites/default/files/project/documents/20150706_143020_26052_m13elecrail_informef inal_Report.pdf

García Alvarez, A., \& Cañizares, M.P. (2010). Metodología de cálculo del consumo de energía de los trenes de viajeros y actuaciones para su reducción. Monografías ElecRail.

Humal, P., Lambot, K., Paul, I. \& Vibo, R. (2018). Major mistakes in Rail Baltica Cost-Benefit Analysis made by Ernst \& Young Baltic. MTÜ ARB. [Accessed 17.03.2018]. Available from Internet: https://avalikultrailbalticust.ee/PDF/ARB_MMistakesRB_CBA_by_EY.pdf

International Energy Agency, database.(2017). [ Accessed 05.04.2019 ]. Available from Internet: https://www.iea.org/statistics/kwes/

IEA ETSAP. (2011). Technology Brief: Rail Transport. [Accessed 14.08.2018]. Available from Internet: https://iea-etsap.org/E-TechDS/PDF/T11_Rail_Transport_v3_final_gs06062011.pdf

IEA \& UIC. (2017). Railway Handbook. Energy consumption and CO2 emissions. Focus on Passenger Rail Services. Paris.[Accessed 21.03.2019]. Available from Internet: https://https://uic.org/IMG/pdf/handbook_ieauic_v3.pdf

International Union of Railways (UIC). (2016). Carbon Footprint of Railway Infrastructure. Comparing existing methodologies on typical corridors. Recommendations for harmonized approach..[Accessed 21.03.2019]. Available from Internet: https://uic.org/IMG/pdf/carbon_footprint_of_railway_infrastructure.pdf

Jehanno, A. (2011). High-speed rail \& sustainability. Report for International Union of Railway (UIC), Paris. [Accessed 14.03.2019]. Available from Internet: https://www.fra.dot.gov/Elib/Document/15010

Jurado, R.R.(2012). Ferrocarril y energía para todos los públicos. Revisión crítica de datos sobre consumo de energía y emisiones de los medios públicos de transporte. Fundacion de los Ferrocarriles Españoles. [Accessed 04.04.2019]. Available from Internet:

https://www.vialibreffe.com/pdf/Consumo_energ\%C3\%ADa\%20y\%20emisiones_transporte.pdf

Koffi, Brigitte; Cerutti, Alessandro; Duerr, Marlene; Iancu, Andreea; Kona, Albana; Janssens-Maenhout \& Greet (2017). CoM Default Emission Factors for the Member States of the European Union. Dataset Version 2017. European Commission. [Accessed 17.01.2019]. Available from Internet: http://data.europa.eu/89h/jrc-com-efcomw-ef-2017

Miyoshi, G., \& Givoni, M. (2012). The Environmental Case for the High-Speed Train in the UK: Examining the London-Manchester Route. International Journal of Sustainable Transportation 8(2), 107-126. [Accessed 23.04.2018]. Available from Internet: http://dx.doi.org/10.1080/15568318.2011.645124

Seguret, S. (2014). Potential of National Rail Investments in France for Mitigation of Greenhouse Gas Emissions. Presented at the International Conference "Climate Change and Transport". Karlsruhe Institute of Technology. [Accessed 07.09.2018]. Available from Internet: https://www.iip.kit.edu/downloads/6.T4_Seguret.pdf

Union of Railways. (2012). Environment Strategy Reporting System International. Methodology and Policy, 19902030. [Accessed 06.03.2019]. Available from Internet: https://uic.org/IMG/pdf/19902030_environment_strategy_reporting_system.pdf

Von Rozycki C, Koeser H, Schwarz H. (2003). Ecology profile of the German high-speed rail passenger transport system, ICE. International Journal of Life Cycle Assessment 8(2):83-91

Westin, J. \& Kågeson, P. (2012). Can high speed rail offset its embedded emissions? Transportation Research Part D: Transport and Environment, 17(1), 1-7. DOI:10.1016/j.trd.2011.09.006 